\title{
DEVOGELIA (ORCHIDACEAE), A NEW GENUS FROM THE MOLUCCAS AND NEW GUINEA
}

\author{
A. SCHUITEMAN \\ Nationaal Herbarium Nederland, Universiteit Leiden branch, \\ P.O. Box 9514, 2300 RA Leiden, The Netherlands
}

SUMMARY

The new orchid genus Devogelia from the Moluccas and New Guinea is described and illustrated. Its possible affinities are discussed and it is tentatively concluded that Devogelia belongs either to the tribe Cymbidieae or to the Malaxideae. So far a single species, here described as D. intonsa Schuit., is known, which occurs as a locally abundant terrestrial in lower montane forest.

Key words: Orchidaceae, Devogelia, New Guinea, Moluccas, taxonomy.

\section{INTRODUCTION}

New orchid genera are still described every year, at an average rate of about thirteen in the past decade. Most of these represent groups of known species split off from existing genera rather than truly new discoveries. It is a rare event, and it is becoming increasingly more so, that an undescribed orchid species turns out to be so distinct that it cannot be satisfactorily accommodated in any known genus. This is the case with a rather large orchid of which four collections are known, one from Obi Island in the Moluccas, and three from the Bird's Head Peninsula in West New Guinea. The most distant localities where this new species was found are separated by no less than $500 \mathrm{~km}$.

One of the collections had been identified as Plocoglottis spec. (Van Royen \& Sleumer 8233), a second as Eulophia spec. (Van Royen \& Sleumer 7355), while the others had wisely been left unnamed (De Vogel 4175, Mahyar 5083).

The general impression is indeed of a species of Plocoglottis: the plants have oneleaved pseudobulbs along a creeping rhizome, plicate leaves and very tall, unbranched inflorescences with flowers opening in succession or a few at a time, and which have four pollinia. There is also an ecological similarity: Plocoglottis is a genus of terrestrial orchids growing in forests at moderate elevations, as is the new species to be described here. A closer analysis quickly reveals that this general impression is wrong. Plocoglottis can clearly be ruled out, but so can any other known orchid genus.

Morphologically, Devogelia intonsa, as the new species will be called, does not possess any particularly outstanding features. The shape of the lip is paralleled in Calanthe, Claderia, and Eulophia, among others, the column is of relatively simple structure, and the vegetative parts are reminiscent of Plocoglottis and Tainia, although the very long cataphylls and the terminal inflorescences are different. The four separate pollinia without caudicles or stipe occur also in Liparis and other genera. The combination of characters, however, is unique: as if parts of distantly related orchids have been welded 
together. Consequently, it is difficult to pinpoint the nearest relatives of Devogelia.Apart from the fact that it is obviously a member of the subfamily Epidendroideae, little else can be said with any confidence. The genus may belong to the tribe Cymbidieae, but other evidence, as explained below, indicates an affinity with the Malaxideae. Hopefully a DNA analysis can be performed in the near future to gain more insight in the systematic position of the currently enigmatic Devogelia.

\title{
Devogelia Schuit., gen. nov.
}

\begin{abstract}
Herba terrestricola sympodialis. Pseudo-bulbi relative breves internodiis paucis cataphyllis multissime longioribus involuti 1- vel 2-foliati. Folia longe petiolata plicata inarticulata basi haud vaginata. Racemus terminalis hysteranthus glaber elatus multiflorus, pedunculi squamis distantibus tubulosis, floribus succedaneis vel paucis in anthesi. Bracteae breves persistentes. Sepala libera glabra. Petala libera. Labellum ecalcaratum immobile 3-lobatum parte basali pilis subulatis dense tecta. Pollinia 4 inappendiculatis. - Typus: Devogelia intonsa Schuit.
\end{abstract}

Sympodial terrestrial herb. Pseudobulbs relatively short, consisting of a few internodes, enveloped by very much longer cataphylls, 1 - or 2-leaved. Leaves long petiolate, plicate, inarticulate, not sheathing at the base. Inflorescence terminal, hysteranthous, glabrous, a tall, many-flowered raceme, with distant, tubular peduncle-scales; flowers opening in succession or a few at a time. Floral bracts short, persistent. Sepals free, glabrous. Petals free. Lip not spurred, immobile, 3-lobed, densely covered with subulate hairs in the basal part. Pollinia 4, solid, without appendages.

A single species is known:

Devogelia intonsa Schuit., spec.nov. - Fig. 1

Folia anguste elliptica usque $60 \mathrm{~cm}$ longa. Racemus circa 10-florus. Petala basi sparse pubescentia. Labellum profunde 3-lobatum circa $13 \mathrm{~mm}$ longum latumque ubi applanatum, lobis lateralibus latis subfalcatis rotundatis, lobo medio breviter ungulato bilobulatis lobulis latis late divergentibus rotundatis. - Typus: De Vogel 4175 (holo L), Indonesia, Moluccas, Obi Island.

Rhizome creeping (only fragments preserved), $3-5 \mathrm{~mm}$ thick. Roots not or sparsely branching, densely shortly pubescent, $2-3 \mathrm{~mm}$ thick. Pseudobulbs c. $2.5 \mathrm{~cm}$ apart, broadly ovoid, $1.5-3$ by $1-2 \mathrm{~cm}$, consisting of c. 4 internodes, enveloped in 3 or 4 relatively very long cataphylls, which increase in size upwards, the largest $12-30 \mathrm{~cm}$ long, 1-leaved, sometimes with a much narrower second leaf; on older pseudobulbs the cataphylls dissolve into fibres and wither away. Leaves erect, rather stiff, long petiolate, inarticulate, duplicate or convolute?; petiole $15-42 \mathrm{~cm}$ long, channelled; blade plicate, narrowly elliptic, $32-60$ by $2.8-5.7 \mathrm{~cm}$ (second leaf linear, $1-1.3 \mathrm{~cm}$ wide), acuminate, many-veined, with about 5 prominent veins below. Inflorescence 43-110 $\mathrm{cm}$ tall, terminal from the axil of the uppermost leaf, racemose, glabrous, 9-11-flowered, the flowers opening in succession or a few at a time; peduncle terete, 40-104 cm long, with 5-7 widely spaced tubular, oblique scales that become progressively shorter upwards; rachis relatively very short, $3-6 \mathrm{~cm}$ long, terete, distance between successive flowers 3-6 mm. Floral bracts persistent, glabrous, suborbicular, concave, c. 2 by $2 \mathrm{~mm}$, rounded-obtuse. Pedicel and ovary terete, weakly 6-ribbed, glabrous, 


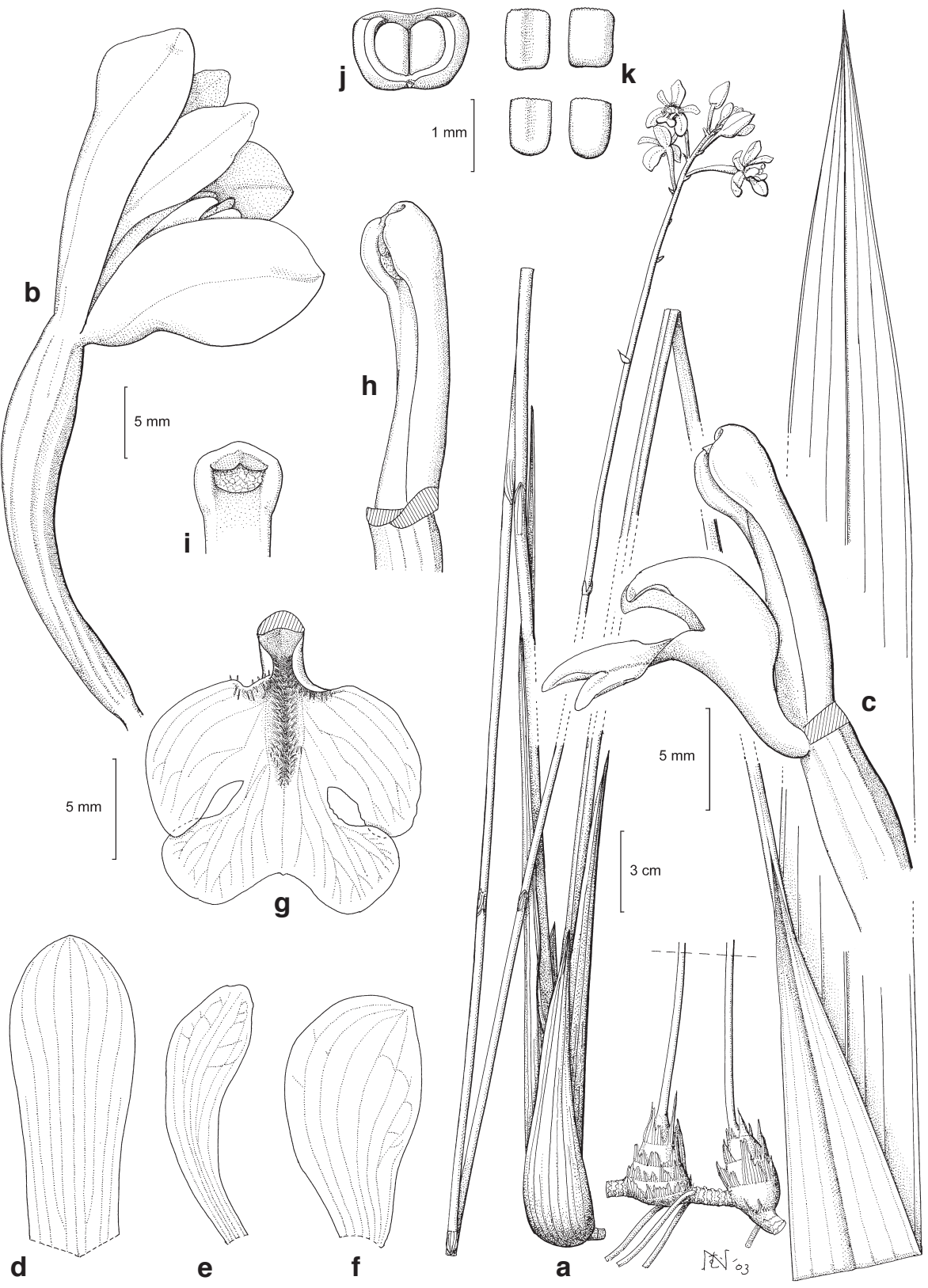

Fig. 1. Devogelia intonsa Schuit. a. Habit; b. flower; c. lip and column; d. median sepal; e. petal; f. lateral sepal; g. lip; h. column; i. column apex in ventral view; j. anther; k. pollinia (all: De Vogel 4175). 
20 (-30) $\mathrm{mm}$ long, $2 \mathrm{~mm}$ diam., twisted at the base. Flower relatively small, resupinate. Sepals free, glabrous, 9-veined. Median sepal subspathulate-oblong, 16.3-21(-24) by 6-6.3(-7) $\mathrm{mm}$, apex rounded-subacute. Lateral sepals obliquely subspathulate-obovate, $12.5-15(-17)$ by $7(-9) \mathrm{mm}$, apex broadly rounded-subacute. Petals free, inside at the base with a few scattered, subulate hairs, obliquely subspathulate, subfalcate, $12.5-20(-21)$ by $3.5-3.8 \mathrm{~mm}$, apex rounded-obtuse, apical margin slightly irregular, 5 -veined. Lip shortly clawed, deeply 3 -lobed, immobile, when flattened $12-13.8$ by $12-14.3(-15) \mathrm{mm}$, margins entire; claw 2.5 by $2.2 \mathrm{~mm}$, margins erect-incurved; basal part of the lip with two broad, swollen, parallel keels that extend to the base of the claw of the mid-lobe, the keels separated by a narrow groove and gradually widening towards the lip apex; the claw, the keels, and the lateral lobes near their basal margins very densely covered with c. $1.5 \mathrm{~mm}$ long, subulate, unicellular hairs; lateral lobes erect, falcate, obliquely ovate, free part c. $3.7(-4.5) \mathrm{mm}$ long, rounded; mid-lobe reflexed, when flattened 10-12.5 mm wide, shortly and broadly clawed, deeply bilobulate with broad, widely divergent, broadly rounded to subtruncate lobules, minutely apiculate in the sinus between the lobules, on the adaxial surface with raised veins. Column erect, sparsely hairy in front at the base, otherwise glabrous, almost straight to curved, very slightly winged along the upper margins, 15 by $4.5 \mathrm{~mm}$, with a c. $2 \mathrm{~mm}$ long, straight foot; stigma transverse, with somewhat swollen lower margin; rostellum transverse, broad, truncate, with three longitudinal folds, one in the centre and two near the sides, of which the median one is the most prominent. Anther in outline transversely subrectangular with rounded corners, glabrous, 1.2 by $1.6 \mathrm{~mm}$. Pollinia 4 , in two pairs, superposed, those of a pair slightly unequal, the largest 0.9 by $0.6 \mathrm{~mm}$, in outline rectangular with rounded corners, concave on one side, the smallest similar but slightly smaller, without appendages (see note 1 below). Fruit not seen. (Description of the vegetative parts, the inflorescence, the anther and the pollinia from dried material only. The measurements based on spirit material, when outside the range of the rehydrated herbarium material, between brackets)

Colours - Flower green, lip creamy-green with brown front margin, central line and base; column greenish white (type), or flower green, lip yellow or white with three yellow stripes in the centre and along edge of mid-lobe; column pale yellow. Leaves dark green, light green below, pseudobulbs blackish green (Van Royen \& Sleumer specimens). Finally, Mahyar 5083 is described as having green sepals and petals, a greenish white lip with brown margins at the junction of mid-lobe and lateral lobes, and a white column with brown apical front margins. Possibly parts of the flower turn yellowish with age, as happens in many orchids.

Distribution - Indonesia, Moluccas, Obi Island, Anggai, Gunung Batu Putih, $1^{\circ} 24^{\prime}$ S, $127^{\circ} 48^{\prime}$ E, 19 November 1974, De Vogel 4175 (type L); Indonesia, Papua, Bird's Head Peninsula, south slope of Mt Nettoti, path Andjai-Wekari, 27 November 1961, Van Royen \& Sleumer 7355 (L); descent from Mt Nettoti to Andjai, 7 December 1961, Van Royen \& Sleumer 8233 (K, L; AMES n.v., BO n.v.); Manokwari District, trail to Noteti Hill (?= Mt Nettoti), 1 May 1995, Mahyar 5083 (K, spirit material).

Habitat \& Ecology - Terrestrial in primary hill forest on limestone with rather little undergrowth, altitude $600 \mathrm{~m}$ (type), or in Castanopsis-Nothofagus/oak forest, altitude 1170-1280 m (New Guinea specimens). Locally common. Flowering: May, November, December. 
Notes -1 . In most of the flowers examined the pollinia were not attached to a caudicle or any other kind of appendage, but in one case some irregular tissue was observed sticking to the base of the pollinia. Perhaps a small viscidium is present in the living flower, but this requires confirmation when better material becomes available. Unfortunately, in the only spirit material available, which consists of three detached flowers, all the anthers are missing.

2. Devogelia differs in numerous respects from Plocoglottis, which it superficially resembles. A few of the more salient points include: Terminal and glabrous inflorescence (lateral and pubescent in Plocoglottis); immobile, deeply 3-lobed lip (elastically hinged, entire or weakly lobed lip); pollinia without caudicles (pollinia with large, thick caudicles). Other genera in the subtribe Collabiinae, in which Plocoglottis is currently included (Chase et al., 2003), all differ in at least as many significant characters.

Two more, and totally different, affinities should also be considered. The first is with Claderia and Eulophia in the tribe Cymbidieae. There are some similarities in habit and in the outline of the lip with members of these genera, and moreover, Claderia has terminal (but branched) inflorescences. But these similarities may well be due to convergence, since Devogelia lacks the distinct, large viscidium (or rather combination of stipe and viscidium) that is always found in these genera. Besides, both Claderia and Eulophia have two, not four pollinia, apart from other differences.

Finally, a third potential affinity is with the genus Liparis in the tribe Malaxideae. At first sight this seems the least likely possibility. No known species of Liparis even remotely resembles Devogelia in the morphology of the lip, while also the habit of Devogelia is unparalleled in this genus. And yet, when all character states are carefully considered it will be seen that there are few fundamental differences between the two genera. The following character states of Devogelia are also found in Liparis: Rhizome creeping; roots pubescent, largely unbranched; pseudobulbs one-leaved; pseudobulbs of several internodes; cataphylls much longer than the pseudobulb; plicate leaves; terminal inflorescence; ovary glabrous; flower green; free sepals and petals; sepals glabrous; lateral sepals shorter and broader than the median sepal; immobile lip without a spur; slender column without conspicuous wings, callosities or stelidia; four pollinia without appendages (though possibly with a small viscidium in both genera).

Character states separating Devogelia from Liparis include: Pseudobulbs of several internodes and at the same time one-leaved; leaves both plicate and stiff, rather thicktextured (in Liparis, when plicate, the leaves are rather soft and herbaceous); peduncle with distant, tubular scales; lip with relatively large, falcate lateral lobes and with long, subulate hairs; column with a foot. The very large dimensions of the leaves and inflorescence of Devogelia are also unlike any known species of Liparis.

It would be highly desirable to perform a phylogenetic analysis on Devogelia using DNA data. In view of its similarities to members of various subtribes, one could conjecture that Devogelia occupies a basal position in either the Malaxideae or in the Cymbidieae, but at present this must remain speculation.

3. The new genus is named after Dr. E.F. de Vogel, who collected the type specimen of $D$. intons $a$ and who as of January 2004 formally retired but continues as volunteer taxonomist specialised in Southeast Asian Orchidaceae at the Nationaal Herbarium Nederland. 


\section{ACKNOWLEDGEMENTS}

Dr. J.F. Veldkamp kindly translated the diagnoses into Latin. Mutsuko Nakajima made the fine plate. Having seen Ms. Nakajima's drawing, Mr. P. Ormerod drew my attention to the specimen in the Kew spirit collection. Mr. J.J. Wood kindly enabled me to examine this. Both had independently reached the conclusion that this material represented an unknown genus.

\section{REFERENCE}

Chase, M.W., K.M. Cameron \& R.L. Barrett. 2003. DNA data and Orchidaceae systematics: a new phylogenetic classification. In: K.W. Dixon, S.P. Kell, R.L. Barrett \& P.J. Cribb (eds), Orchid Conservation: 69-89. Natural History Publications (Borneo), Kota Kinabalu, Sabah. 